\title{
The Complementarity between Corporate Governance and Corporate Social Responsibility
}

\author{
Andrea Beltratti* \\ Bocconi University, Instituto di Economia Politica, Via Gobbi 5, 20136 Milan, Italy. \\ E-mail: andrea.beltratti@uni-bocconi.it
}

The paper aims at understanding the relation between corporate governance (CG) and corporate social responsibility (CSR). In theory, CG refers mainly to the mechanisms which protect outsiders and ensure an effective working of the firm, while CSR refers mainly to the objective function of the firm and the attention for various stakeholders. The paper discusses these concepts, with particular attention to the relation between CSR and profit maximization. This relation is important to evaluate which actions are truly socially responsible and which actions are simply profit maximization in disguise. The available empirical evidence shows that both CG and CSR are positively related to the market value of the firm. This suggests that in the long run the market mechanism should be able to provide additional resources to those companies which are best at maximizing a widely defined bottom line.

The Geneva Papers (2005) 30, 373-386. doi:10.1057/palgrave.gpp.2510035

Keywords: corporate governance; corporate social responsibility; stakeholders; ethics; externalities

\section{Introduction}

There is increasing attention to the global impact of large corporations. The global impact includes both economic and social elements. Wealthy economies are not willing to passively accept the decisions made by firms, especially when these amount to inflicting costs to society. A few decades ago, companies could pollute environment with no punishment, and still be considered as beneficial to the community in their role of job providers. Today, there are rules which are sometimes implemented so strictly as to threaten the survivorship of misbehaving companies. Social communities try to influence firms in their normal operations from a variety of points of view, including their goals, transparency and code of behaviour. This influence is exerted by means as diverse as legislation, regulation, pressure groups, political contacts.

In such a complex environment, it is natural that firms react by upgrading their working mechanisms. For example, specific sectors or groups of firms can voluntarily overcomply with external rules by issuing codes of behaviour severely restricting certain aspects of their operations. The existence of such voluntary codes may be

\footnotetext{
* I thank Geoffrey Heal, Isabella Falautano as well as participants at seminars at MPS Vita for interesting comments. A previous version of this paper was presented at the conference on "The paradigms of value. Towards a good governance in financial and insurance services: the challenge of ethics, transparency and trust", organized by Montepaschi Vita and The Geneva Association, in Rome, October 15, 2004.
} 
justified as a credible proof that they want to behave in an acceptable way from the point of view of the community. This paper is concerned with two of the mechanisms used by firms to regulate their operations, known as corporate governance (CG) and corporate social responsibility (CSR).

CG is a well-defined concept related to profit maximization and protection of those economic agents who have provided capital to the firm. CSR is defined less precisely. It evokes a concept apparently in contrast with profit maximization because it suggests a set of actions, which is beneficial to some external stakeholders and may conflict with the interest of the shareholders. However, in practice CSR may not be in contrast with profit maximization, as proven by the existence of many companies, which are proud to present themselves as organizations doing well and doing good at the same time. However, how do we know that these companies, which retrieve benefits from these claims, are really behaving in a socially responsible way? What criteria are required in order to consider a corporate action as a responsible one? If a negative impact on total profits is not required to characterize an action as a responsible one, then how do we know that claims of socially responsible behaviour are not simply a disguised form of publicity? Perhaps companies which are not very active and visible in terms of CSR are simply companies with few occasions to make profitmaximising choices which incidentally are good for other stakeholders. Perhaps, companies which are more visible from the point of view of being socially active really do not care about external stakeholders and are both more lucky or good at finding projects with socially good effects and prompter to communicate these projects to the world.

There is a second issue. Suppose that one accepts the view that CSR is in contrast with profit maximization. Then a contradiction would arise: managers who have been hired to maximize the value of the firm would behave unethically by being socially responsible. They would increase the welfare of some groups of stakeholders at the expense of the welfare of shareholders. This paper claims that there is no contradiction. The relation between CSR and profit maximization is best interpreted by abandoning the standard view of the firm as a shareholder value maximizer and embracing to the more recent view of the firm as a stakeholder value maximizer.

The paper discusses first the definitions of CG and CSR and their applications to the modern corporate sector. While there are many definitions of CG in the economics literature, there are surprisingly few definitions of CSR, which is generally treated by means of examples. This paper tries instead to discuss the general meaning of CSR, noting that socially responsible actions on the part of corporations are more likely under the vision of a firm run to reach a level of profit, which is high but compatible with the welfare of external stakeholders. In this case, socially responsible actions may be frequent and signal attention towards the interests of groups collaborating with the firm. In the final part, the paper looks at the recent wave of corporate scandals and at the role of the financial sector. The financial sector is in some sense an interesting case study after the various examples of bad behaviour which emerged in 2001-2004. The paper asks whether cases of bad behaviour were associated with bad mechanisms of CG or CSR or both, and discusses some of the challenges that the financial sector will have to face in order to overcome these 
episodes. The paper argues that the financial sector was in fault because of problems to both CG and CSR, even though CSR issues were really a primary element. In this sense, the recent history of the financial sector is a prime example of the importance of CSR and of the negative externalities, inflicted to the economy as a whole by failures in socially responsible behaviour.

After this introduction, the second section looks at corporate governance, in order to discuss its theoretical basis and what is known about the impact of $\mathrm{CG}$ for the value of the firm. The third section looks at some relevant empirical evidence on CSR, from the point of view of both the supply of CSR (the cost to the firm of being socially responsible) and the demand of CSR (the cost to the financial investor in selecting socially responsible firms). This empirical evidence discussed in the fourth section is relevant for a discussion of CSR from a theoretical point of view. The fifth section concludes with some final remarks.

\section{Corporate governance}

Corporate governance may be interpreted as a reaction to agency problems, associated with the separation between owners and managers. Managers act in the partial pursuit of their personal goals and use inefficiently (from the point of view of the owners) the available resources under circumstances not regulated specifically by the signed contracts. ${ }^{1}$ Typical examples of this are excess size of the firm built to extend the power of the managers, excess remuneration paid to the top management, expropriation of shareholders by means of pyramid scheme and transfer pricing, resistance to replacement on the part of the managers. Becht et al. ${ }^{2}$ therefore establish that "at the most basic level a corporate governance problem arises whenever an outside investor wishes to exercise control differently from the manager in charge of the firm".

Problems are not restricted to the interaction between managers and owners, but may also occur in the relations among owners, especially when they are very heterogeneous in terms of relevance. There are various cases where minority shareholders lose from the actions of majority shareholders who exploit their control power. Therefore CG can be defined more generally as "a set of mechanisms through which outside investors protect themselves against expropriation by the insiders". 3 Shleifer and Vishny $(1997)^{4}$ claim that "the fundamental question of corporate governance is how to assure financiers that they get a return on their financial investment".

Therefore $\mathrm{CG}$ is a complex issue. It involves problems between owners and managers, between owners themselves and between stakeholders. There is a CG problem whenever one or more groups of stakeholders coordinate their actions in order to increase their benefits at the expense of the benefits of the other stakeholders.

\footnotetext{
${ }^{1}$ See Jensen and Meckling (1976).

2 Becht et al. (2003).

${ }^{3}$ La Porta et al. (2002).

${ }^{4}$ Shleifer and Vishny (1997).
} 
It is no wonder that in complex companies $\mathrm{CG}$ is such a crucial issue. There are various tools to ensure an effective CG. It is possible to distinguish between internal and external tools. Among the most important internal tools, one can include concentration of control rights in the hands of a small number of shareholders who have the incentive to monitor the managers, efficient mechanisms for the formation of the board of directors, renumeration structures for managers which are anchored to performance. Among external tools, one can think of control of outside stakeholders, especially banks and financial institutions, and the takeover threat from other firms, which may impose discipline on the managers whenever they do not maximize the value of the company.

Are these tools effective? Empirical analyses show that the answer is often positive. La Porta et al..$^{5}$ study the impact of the legal protection of minority shareholders and of the share of the cash flow controlled by the majority shareholder on the value of the firm and find a positive relation. Cremers and Nair ${ }^{6}$ find that firms with strong internal and external governance produce a higher (10-15 per cent) return to shareholders than firm characterized by weak governance. Drobetz et al. ${ }^{7}$ find a positive association between governance indicators and value of the firm in Germany. Smith ${ }^{8}$ claims that the inclusion of a firm in the list of CalPERS (California Public Employee's Retirement System) has important impacts on the corporate governance structure of the firm ( 70 per cent of the included firms act to improve their CG structure) under observation and on the market value, even though there are few effects on operating cash flows. The cost-benefit analysis is positive for CalPERS: in the period 1987-1993, activism costs $\$ 3.5$ million but the benefit is $\$ 19$ million.

There are however exceptions. Even single reference shareholders may fail to maximize the value of the company and may even damage minority shareholders and stakeholders in general, as the Parmalat case has shown in 2003, an episode which points out the relevance of the legal protection of the votes discussed by Shleifer and Vishny. ${ }^{9}$ Even shareholders' activism has not been found to be very effective. ${ }^{10}$ There are many discussions about boards of directors and the role of independent directors, ${ }^{11}$ for example, connected with the role of the CEO of the corporation for his election. Empirical evidence on the effectiveness of independent directors is mixed. ${ }^{12}$ According to many, compensations connected with the value of the firm has been one of the main incentives for the burst of "creative accounting" of the second part of the 1990s with the subsequent problems. Moreover, on average the sensitivity of managers' wage to change in wealth of shareholders is low. ${ }^{13}$ Bank control has not

\footnotetext{
${ }^{5}$ La Porta et al., op. cit.

${ }^{6}$ Cremers and Nair (2003).

${ }^{7}$ Drobetz et al. (2003).

${ }^{8}$ Smith (1996).

${ }^{9}$ Shleifer and Vishny, op. cit.

${ }^{10}$ See Romano (2001).

${ }^{11}$ See for example Bhagat and Black (2001).

12 See Becht et al. (2003).

${ }^{13}$ See Shleifer and Vishny, op. cit.
} 
been particularly effective in Germany and Japan - the most important contemporary experiments - and may actually give rise to inefficiencies if the criteria used by banks to provide loans are affected by the existence of ownership. Takeovers are very infrequent: Becht et al. ${ }^{14}$ show that in the U.S. the takeover rate has been infrequently above 1.5 per cent and the hostile takeovers are in general 30 per cent of the total takeovers. There are good reasons for this, connected with the high costs of acquisitions. Also the impact of active institutional shareholders is unclear: Gillan and Starks ${ }^{15}$ find little impact of resolutions on operating income and some impact on CG. Black is a pessimist and claims that "... a small number of American institutional investors, mostly public pension plans, spend a trivial amount of money on overt activism efforts. The current available evidence... is consistent with the proposition that the institutions achieve the effects on firm performance that one might expect from this level of effort - namely, not much". ${ }^{16}$

In conclusion, $\mathrm{CG}$ has become a crucial issue, but there does not seem to be a perfect recipe for implementing tools which ensure the best possible CG. The complexity of organizations allows many possibilities for illegal behaviour on the part of some stakeholders. Moreover, it is always very hard to tell the cases where stakeholders are really interested in the value of the firm from cases where stakeholders pursue a personal objective. The many externalities associated with the efficient working of the firm are also a deterrent for costly and serious involvement on the part of various groups.

\section{Corporate social responsibility}

From a definitional point of view, CSR is in some sense the opposite of CG: there are thousand of case studies but few theoretical discussions. The few existing definitions are perhaps too general and far from theory. The Commission of the European Communities ${ }^{17}$ defines CSR as a concept by which "companies decide voluntarily to contribute to a better society and a cleaner environment". It also says that behaving in a socially responsible way amounts to "going beyond compliance and investing 'more' into human capital, the environment and the relations with stakeholders". The OECD ${ }^{18}$ claims that "the common aim of the governments adhering to the Guidelines is to encourage the positive contributions that multinational enterprises can make to economic, environmental and social progress, and to minimize the difficulties to which their various operations may give rise". This may be generalized by referring to the concept of business ethics, discussed at length by Payne. ${ }^{19}$ Hopkins claims that "CSR is concerned with treating the stakeholders of the firm ethically or in a responsible manner. Ethically or responsible means treating stakeholders in a manner

\footnotetext{
${ }^{14}$ Becht et al. (2003).

${ }^{15}$ Gillan and Starks (1998, 2000).

16 Black (1998).

${ }^{17}$ The Commission of the European Communities (2002).

18 OECD (2003).

19 Payne (2003).
} 
deemed acceptable in civilized societies". ${ }^{20}$ If the firm is regarded as a living organism, then it is natural to believe that good firms will behave in an ethical and socially responsible way, and will try to induce an ethical behaviour on the part of its employees.

These definitions stress the equivalence between CSR and ethics and, surprisingly, do not explicitly refer to the link between CSR and profit maximization. The presumption of the previous definitions is that CSR negatively impacts profits: behaving responsibly may be costly (in terms of utility) to an individual with a low level of ethics, so that behaving in a socially responsible way may be costly (in terms of profits) to a firm. Investing 'more' into human capital and the environment may well decrease profits, and the same happens in terms of contributing to a better society. Indeed, if these objectives were achievable in the normal search for profit maximization, one doubts that firms would need the idea of CSR at all.

To analyse CSR more systematically, and to study the relation between CSR and profit maximization, it is useful to discuss the motivations behind various cases of responsible behaviour on the part of the firm: (i) managers may decide that the firms behave in a socially responsible way at the expense of profits in order to retrieve private interest, associated with the rewards that the community may ensure to the promoters of the responsible behaviour of the company; (ii) managers may decide that the firms pursue profit maximization but exploit actions, which are incidentally also in the interest of some group of stakeholders to claim a socially responsible behaviour; (iii) managers may decide that the firm must be socially responsible, even at the cost of deviating from profit maximization and without increasing their private utility.

It is claimed that cases (i) and (ii) represent opportunistic behaviour. Case (i) is sufficiently clear and does not warrant a particular discussion. Case (ii) is more interesting. In case (ii) it is not correct to claim that a profit maximizing choice is an example of CSR, unless one could show that there were other actions, which were even more profit maximizing but were deliberately not followed by the firm in the attempt to safeguard the interest of some group of stakeholders. Imagine the case of a company which develops a profitable and environment friendly innovation. Is this a true example of CSR? Not necessarily. It may be that firms knew that these decisions would have increased profits and simply wanted to further increase profits by exploiting an astute communication to the public, a scenario which would push many people to doubt, if not the positive social effects of the decision, at least the degree of ethics of the firms themselves. ${ }^{21}$ There are theoretical models, which are compatible with the view that managers try to do well, and incidentally do good. For example, Arora and Gangopadhyay ${ }^{22}$ show that overcompliance on the part of a firm may actually be a profit maximizing strategy aimed at inducing stricter regulation, which may be troubling to other competitors which are not efficient enough to comply.

\footnotetext{
${ }^{20}$ Hopkins (2004).

${ }^{21}$ Even more disturbing to believers in the rationality of institutions, if the firms would not have known about the potential for profit maximization associated with choices, which are also socially responsible, there was a failure of competency of managers, who would not have explored well all the alternatives offered by research and technology.

${ }^{22}$ Arora and Gangopadhyay (1995).
} 
Overcompliance is generally regarded as an example of CSR, but it may be a strategy to maximize profits.

Case (iii) deserves more attention, because it may hide a paradox: managers pursuing CSR at the expense of profit maximization would behave unethically from the point of view of not respecting the contracts which they have signed with the owners of the firm, unless the socially responsible behaviour was dictated by the owners themselves. In general however it seems unlikely that shareholders are unanimous in dictating a responsible behaviour. Are managers unethical towards the subset of owners interested in profit maximization?

Under general conditions it is unclear why managers should direct the firm with an eye towards the exclusive interest of the shareholders. Jensen and Meckling ${ }^{23}$ show that if (a) the firm is a nexus of contracts with stakeholders, (b) only shareholders carry all the residual risk and (c) there are no agency problems, then value maximization amounts to economic efficiency. Agency problems are generally present so that value maximization in general does not coincide with economic efficiency. Shareholders and other stakeholders may have divergent goals, and it is unclear why managers should choose to follow the former, even though there are reasons proposed by Williamson ${ }^{24}$ (shareholders are less protected than others and their work is sunk into the firm) and Hansmann ${ }^{25}$ (shareholders may better coordinate among themselves and produce a better decision process). Therefore, profit-decreasing CSR may be justified by the existence of agency problems and incomplete contracts which undermine the basic idea of shareholders' leadership.

Viewing CSR in this enlarged framework is essential in order to properly evaluate practical cases. If profit maximization is taken as the basic goal of the firm, then it may be difficult to both find true examples of CSR and justify managers pursuing CSR. Under these circumstances in fact any socially responsible action would be taken in response to a need of a stakeholder and would imply a profit-decreasing choice on the part of the managers. However, under a more general view of firms as stakeholders' interest maximizers, managers may try to reconcile the objects of both shareholders and other stakeholders, taking actions which are compatible with a win-win scenario where both profits and welfare improve. In this case, it may be perfectly sound to find many projects, which increase profits and at the same time benefit other shareholders.

\section{Empirical results about CSR}

There are two relevant pieces of evidence. The first is related to direct and indirect analyses of the effect of CSR on firms' profits, and the second to the performance of the socially responsible investments. These two pieces of evidence are relevant because they look at two different angles of the value creation process, that is the cost to the supplier of social responsibility (the firm) and to the demander of the same good (the investor).

\footnotetext{
23 Jensen and Meckling (1976).

${ }^{24}$ Williamson (1985).

${ }^{25}$ Hansmann (1996).
} 


\section{The direct cost of CSR}

Starting from the supply side, Payne ${ }^{26}$ claims that risk management is one of the goals of corporations' ethics; by upgrading the ethical and social values of the corporation and its employers one may hope to minimize the cases of bad behaviour and the potentially negative consequences on the value of the firm. For example, the Shareholder Action Network (SAN) accuses ExxonMobil of weak sensitivity (worse than the average of the industry) to issues like climate change and alerts to the possibility that there are risks connected with future claims on the part of stakeholders who in the future may be damaged by climate change and consequently by the lack of action of the company. In this case, CSR is positively related to the value of the firm from the point of view of minimizing future possible liabilities associated with lack of social responsibility.

Another positive effect of CSR and ethical values is associated with improvements in organizations through innovation, ${ }^{27}$ cooperation, motivation on the part of the workers, branding of the corporation in the relevant market by constructing a special relationship with the stakeholders, especially clients and intermediate suppliers.

While it may be difficult to place a value on the reputation of the firm in terms of CSR, indirect evidence is available. Karpoff and Lott ${ }^{28}$ show that the decrease in share prices following news about illegal actions on the part of the firm is largely associated with damage to reputation, only 6 per cent is associated with the objective estimate of the damage. Anderson and $\mathrm{Yohn}^{29}$ find that the stock market reacts with a negative return of almost 4 per cent to news about the necessity of income restatements. Palmrose et al..$^{30}$ propose a similar analysis for the period 1995-1999 and find an even larger estimate of -9 per cent, with an even lower return in cases of illegal behaviour on the part of the management. Elayan et $a l .{ }^{31}$ analyse the reaction of stock prices to news of accounting irregularities and find an effect of -25 per cent in the 3 days following the announcement, -5 per cent in the 90 days preceding the piece of news, -60 per cent in the overall period of 180 days surrounding the event. The reaction is connected with the existence of informational asymmetries, for example, in the case of small firms and high tech firms and in those firms where the management is perceived as receiving a higher salary, probably because in those cases there is a higher probability that the management is trying to expropriate the other stakeholders.

There are various studies also on the direct relation between CSR and firm value. It is worth mentioning some studies which represent an overview of the empirical literature. Margolis and Walsh ${ }^{32}$ compare the results of 95 studies which globally take into account 70 financial indicators and 11 social indicators. In all, 55 out of 95 find a positive relation; only four studies find a negative relation. Orlitzky and

\footnotetext{
${ }^{26}$ Payne, op. cit.

${ }^{27}$ See also various examples provided by Heal (2004).

${ }^{28}$ Karpoff and Lott (1993).

${ }^{29}$ Anderson and Yohn (2001).

${ }^{30}$ Palmrose et al. (2001).

31 Elayan et al. (2002).

${ }^{32}$ Margolis and Walsh (2001).
} 
Benjamin $^{33}$ find that CSR is inversely related to overall risk, for example, the risk of being involved in legal disputes about pollution, health damage, regulation. Orlitzky et $a l .{ }^{34}$ study the relationship between CSR and the financial performance of the firm, and find a positive sign. Overall, CSR seems to be positively connected with profits.

\section{The cost of socially responsible investment}

The previous paragraph has shown that CSR may not necessarily be a cost to the firm. On the contrary, there are theoretical reasons to believe that CSR may have a positive impact on value, and empirical analyses showing the existence of a positive relation. On the basis of this evidence, one would expect to find little or no cost also from the point of view of the financial investor following principles of social responsibility. The available evidence shows that this is indeed the case.

One way to understand this is to look at socially responsible indices of stock performance. Three important indices are the Domini 400, started in 1990 and based in the U.S. market, the Dow Jones Sustainability Index started in 1999 and the more recent FTSE4Good, started in 2001. The three indices are based on partially different inclusion criteria: Domini excludes some specific sectors on the basis of the estimate of their social damage, Dow Jones Sustainability Index does not discriminate on the basis of belonging to a specific sector but only includes firms which satisfy minimum requirements as far as issues like environmental sustainability and human rights are concerned.

Corten $^{35}$ compares the historical performance of such indices with comparable indices from the point of view of average return and volatility of return. The results show that the socially responsible indices behave better than the respective benchmarks. For example, the social index Ethibel World over the period 1998$2003 \mathrm{had}$ an average return (2.25 per cent) superior to that offered by the index MSCI World ( 0.54 per cent) and a higher volatility ( 21 per cent against 19 per cent). The Dow Jones Sustainability Index produced an average return of 1.72 per cent (with a volatility of 21 per cent) over the same period against 1.42 per cent (with a volatility of 20 per cent) of the Dow Jones Global. In 1990-2003 The Domini Social on average increased by 13 per cent with a volatility of 16 per cent against values of 12 per cent and 15 per cent for the S\&P500. There are of course exceptions: the FTSE4Good decreased 14 per cent in 2001-2003 with a volatility of 23 per cent against a decrease of only 12 per cent (with a volatility of 22 per cent) for the FTSE Europe. However, what is relevant is that there does not seem to be any systematic downward bias in the return of the socially responsible indices with respect to appropriate benchmarks. Actually, a performance analysis based on the three factor Fama and French ${ }^{36}$ model reveals that the SRI indices in general overperform the benchmarks when one takes into account the systematic risk associated with size and value effects. ${ }^{37}$

\footnotetext{
33 Orlitzky and Benjamin (2001).

34 Orlitzky et al. (2003).

${ }^{35}$ Corten (2004).

${ }^{36}$ Fama and French (1996).

${ }^{37}$ See Corten, op. cit.
} 
Other empirical analyses, conducted on the basis of the performance of socially responsible mutual funds, produce similar results. ${ }^{38}$ An early study is Grossman and Sharpe ${ }^{39}$ which looks at the financial implications of discrimination against firms which at the time did business with South Africa. The authors show that the socially responsible portfolio produces a return 0.26 per cent higher than the benchmark for the stock market, which is reduced to 0.19 per cent with a risk correction to take account of larger investment in small firms. More recently, Geczy et al. ${ }^{40}$ show that the opportunity of limiting the investment universe to SRI funds is negligible if the goal of the investor is replicate the performance of the market index, and becomes substantial (3.6 per cent) only when the investor wants to do active fund management.

\section{The corporate scandals of 2001-2004}

The period 2001-2004 involved a number of corporate scandals. The most discussed cases had to do with accounting irregularities, which were spread across sectors, from telecommunications to oil. Benston et al. ${ }^{41}$ suggest that accounting irregularities are not a new phenomenon in the U.S., even though their characteristics have evolved over time. Between 1987 and 1997 Beasley et al. ${ }^{42}$ show that these cases were concentrated among smaller firms and were in general restricted to issues like non existing revenues, even though there has been a trend upward. A study of the Financial Executives International ${ }^{43}$ has found 224 cases between 1977 and 1989, 392 between 1990 and 1997 and 464 between 1998 and 2000. Palmrose and Scholz ${ }^{44}$ identify 492 cases between 1995 and 1999 divided among years as: 44, 48, 90, 106 and 204, respectively. To put things in perspective one should remember that the number of firms reporting to SEC is about 17,000. In other countries there is less analysis of this problem, but it is likely to be important given a lower level of protection of shareholders. Leuz et al..$^{45}$ indeed show that the tendency to actively manage earnings is inversely proportional to the degree of shareholders' protection. What was new in 2001-2004 was the size of the firms involved in the scandals given the large dimensions of Enron, Worldcom, Xerox and others. ${ }^{46}$

The financial industry has also been affected by many scandals, for example (a) mutual funds and hedge funds, market timing and late trading: mutual funds have permitted market timing (formally a legal activity) and late trading on the part of

${ }^{38}$ See for example Hamilton et al. (1993); Mallin et al. (1995); Gregory et al. (1997); Reyes and Grieb (1998).

${ }^{39}$ Grossman and Sharpe (1986).

${ }^{40}$ Geczy et al. (2003).

${ }^{41}$ Benston et al. (2003).

${ }^{42}$ Beasley et al. (1999).

${ }^{43}$ Financial Executives International (2001).

${ }^{44}$ Palmrose and Scholz (2002).

${ }^{45}$ Leuz et al. (2003).

${ }^{46}$ It is difficult to estimate the damage to the U.S. economy of the scandals. An indirect estimate may be retrieved from Francis et al. (2005), which finds that lower quality of earnings implies a higher cost of capital of 80-160 basis points for debt and 150-300 for equity. Graham et al. (2002) have tried a direct estimate by using stock market valuations and find $\$ 35$ billions. 
hedge funds, with many direct and indirect costs for shareholders, (b) IPOs: shares in hot IPOs were preferentially given to important personal clients in order to obtain investment banking contracts in return, (c) analysts: this has been the most widely discussed financial scandal, with analysts giving favorable advice on shares in order to help their performance after the IPO; (d) soft commissions: a mutual fund pays a higher price for each transaction to a broker in exchange for research and other activities, which in this way are ultimately paid by the shareholders, (e) directed brokerage: in this variant of soft commissions, mutual funds pay higher prices for transactions in order to convince the brokers to sell the funds to the public, (f) specialists at the NYSE: in February 2004 SEC received a payment of \$240 millions from five specialist firms as a compensation for stock price manipulations.

What went wrong in these cases? Was there a CG failure or a CSR failure or both? The most famous cases certainly were $\mathrm{CG}$ failures. Accounting tricks and offshore companies were clearly aimed at perpetrating frauds against providers of capital and labour. ${ }^{47}$ While these firms were in many cases also apparently brilliant in their CSR (see for example Enron), the truth is that there were examples of gigantic attempts at illegally redistributing wealth towards managers and owners. This could be seen as a CSR issue, a distributional conflict. Holmstrom and $\mathrm{Kaplan}^{48}$ claim that the rise of equity-based compensation has actually been the main reason for the failure of CG in the U.S.

The financial sector has in many cases contributed to these attempts. Helping companies to create offshore companies with the aim of hiding losses is a big failure of CSR. On the other hand, arranging special trading operations between mutual funds and hedge funds in order to increase assets under management, selecting specific wealthy clients for the allocation of hot IPOs and others are also examples of CSR failures. The financial sector has claimed no wrongdoing in most of these cases, however it is clear that financial intermediaries failed to behave in a socially responsible way, neglecting the consequences for specific groups of their choices. The fact that most financial intermediaries decided to pay financial penalties to settle the accusations is probably the best example of what was stated in the introduction, i.e. that societies are not willing to passively accept all the actions coming from the corporate sector. Society has an increasing number of tools to control the decisions of the corporate world.

The financial sector is central in modern economic systems. It is a global industry with numerous business relations with both consumers and other firms. It is therefore at the crossroads of socially responsible behaviour. The financial sector needs to become highly socially responsible, in such a way as to perform a credible role as an instrument for improving the CSR of other sectors. There are various ways to do this, associated with considering the social performance of their clients as an important requisite for providing financing and insurance.

While this is a general target, there are some specific paths that the financial sector has to take in order to become a point of reference for CSR. Among the various areas, particular attention should be devoted to new products, better selection of clients on

\footnotetext{
${ }^{47}$ See for example Alden (2002).

${ }^{48}$ Holmstrom and Kaplan (2003).
} 
the basis of ethical principles, and new communication to clients. New products should be less complicated than current products, unless this is necessary to solve complex allocation problems of groups of individuals. But the center should be the client and not the financial engineering process taking place within the intermediary. Various interesting examples are provided by $\mathrm{Shiller}^{49}$ in discussions of new tools for solving relevant aggregate problems of hedging macroeconomic and sector risks. Better selection has already been mentioned. The financial sector may consider characteristics of firms retrieved from the record in terms of social performance as a way to select best clients. Finally, new communication to clients should better explain existing products and help solve complex asset allocation problems, at the same time stressing the relevance of social criteria in the allocation of credit and insurance.

The CSR role is certain to be costly for financial intermediaries. Allocating credits and insurance contracts by allowing for the behaviour of clients involves new analyses of data, either to be performed internally or, more likely, to be acquired externally by specialized agents. However the increase in costs need not be associated with a decrease in profits. The extra costs may be passed through to final consumers. It is conceivable that by communicating their role of social responsibility monitoring, financial intermediaries may be able to extract more revenues from the pool of socially alert consumers who are willing to pay more for services which are certified to be produced in the context of a process which looks at social responsibility, and is itself socially responsible.

\section{Conclusions}

The corporate sector has been under attack along two lines. First there is the perception that the simple drive for profit maximization may be bad for society as a whole because of some negative by products on the environment, human rights, workers condition and other elements. Second there is the realization that some part of the corporate sector has not been following the basic rules and has illegally extracted resources from stakeholders. In some sense, these attacks arise from failures of both corporate governance and corporate social responsibility. An effective corporate governance system would prevent illegal actions against stakeholders. An effective socially responsible corporate code would prevent actions which are legal but inappropriate because of their consequences on some of their shareholders.

Corporate governance and corporate social responsibility are therefore complementary in their shaping of the objective function and the constraints faced by corporations. They can reinforce each other in the modern vision of the firm as an institution which does not disregard various relevant constituencies in its search for increases in value. The modern and socially responsible firm can go beyond the simple definition of accounting profits if it realizes that such a definition ignores pieces of value which are practically relevant. It does not matter whether accounting profits neglect negative consequences on the environment, violation of human rights and other elements. These elements are crucial to the evaluation of the corporation which is given by society. Fortunately, the modern environment has an increasing number of

\footnotetext{
${ }^{49}$ Shiller (2003).
} 
tools which may be used to induce corporations to move beyond the traditional bottom line and towards an extended bottom line.

Socially responsible firms are often also the most respected and profitable firms. Therefore socially responsible actions are not selected by firms from the pool of profitdecreasing choices. It follows that socially responsible firms do try to maximize profits but at the same time try to improve the welfare of other stakeholders. Firms with a good corporate governance are also more respected and valuable. Therefore a good corporate governance protects the stakeholders which contribute to the life of the firm. Corporate governance and social responsibility are strong complements. The positive relation existing between CG and CSR on the one hand and the market value of the firm on the other hand, suggests that market competition is somehow able to detect the companies which are best also from points of view which are not included in the accounting definition of profit. This is a reassuring hypothesis, which merits more theoretical and empirical analysis.

\section{References}

Alden, F. (2002) 'Structural deception by banks in Enron case', Financial Times, July 24.

Anderson, K.L. and Yohn, T.L. (2001) The effect of 10.k restatements on returns and information asymmetry, working paper, Georgetown University.

Arora, S. and Gangopadhyay, S. (1995) 'Toward a theoretical model of voluntary overcompliance', Journal of Economic Behavior and Organization 28: 289-309.

Beasley, M.S., Carcello, J.V. and Hermanson, D.R. (1999) Fraudulent financial reporting: 1987-1997: An analysis of public companies, Jersey City, NJ: American Institute of Certified Public Accountants.

Becht, M., Bolton, P. and Roell, A. (2003) 'Corporate governance and control', in G. Constantinides, M. Harris and R. Stulz (eds) Handbook of the Economics of Finance, Amsterdam: North-Holland, pp. 1-126.

Benston, G., Bromwich, M., Litan, R.E. and Wagenhofer, A. (2003) Following the money, AEI-Brookings Joint Center for Regulatory studies, Washington, DC.

Bhagat, S. and Black, B.S. (2001) 'The non-correlation between board independence and long term firm performance', Journal of Corporation Law 27: 231-273.

Black, B.S. (1998) 'Shareholder activism and corporate governance in the United States', in P. Newman (eds), The New Palgrave Dictionay of Economics and the Law 3: 459-465.

Commission of the European Communities (2002) Communication from the Commission concerning Corporate Social Responsibility: A business contribution to sustainable development, Brussels.

Corten, F. (2004) 'Sustainable indices: Risk and return characteristics', Investment \& Pensions Europe, SRSI Report (April): 19.

Cremers, K.J.M. and Nair, V.B. (2003) Governance mechanisms and equity prices, working paper no. 03-15 Yale International Center for Finance.

Drobetz, W., Schillofer, A. and Zimmermann, H. (2003) Corporate governance and expected stock returns: Evidence from Germany, working paper no. 2/03, WWZ Department of Finance.

Elayan, F.A., Li, J. and Meyer, T.O. (2002) Accounting irregularities, management compensation structure and information asymmetry, working paper, Massey University.

Fama, E.F. and French, K.R. (1996) 'Multifactor explanations of asset pricing anomalies', Journal of Finance 55: 55-84.

Financial Executives International (2001) Quantitative measures of the quality of financial reporting, Morristown, NJ: FEI Research Foundation.

Francis, J., LaFond, R., Olsson, P. and Schipper, K. (2005) 'The market pricing of accruals quality', Journal of Accounting and Economics 2: 295-327.

Geczy, C.C., Stambaugh, R.F. and Levin, D. (2003) Investing in socially responsible mutual funds, working paper, University of Pennsylvania.

Gillan, S.L. and Starks, L.T. (1998) 'A survey of shareholder activism: Motivation and empirical evidence', Contemporary Finance Digest 2: 10-34. 
Gillan, S.L. and Starks, L.T. (2000) 'Corporate governance proposals and shareholder activism: The role of institutional investors', Journal of Financial Economics 57: 275-305.

Graham, C., Litan, R. and Sukhtankar, S. (2002) The bigger they are, the harder they fall: An estimate of the cost of the crisis in corporate governance, working paper, The Brookings Institution.

Gregory, A., Matatko, J. and Luther, R. (1997) 'Ethical unit trust financial performance: Small company effects and fund size effects', Journal of Business Finance and Accounting 24: 705-725.

Grossman, B.R. and Sharpe, W.F. (1986) 'Financial implications of South African divestment', Financial Analysts Journal 42: 15-29.

Hamilton, S., Jo, H. and Statman, M. (1993) 'Doing well while doing good? The investment performance of socially responsible mutual funds', Financial Analysts Journal 49: 62-66.

Hansmann, H. (1996) The ownership of enterprise, Cambridge, MA: The Belknap Press of Harvard University.

Heal, G. (2004) Corporate Social Responsibility - An Economic and Financial Framework, working paper, Columbia Business School.

Holmstrom, B. and Kaplan, S.N. (2003) The state of U.S. corporate governance: What's right and what's wrong?, Boston: National Bureau of Economic Research working paper No. 9613.

Hopkins, M. (2004) Corporate social responsibility: An issues paper, ILO, Geneva: Working paper No. 27.

Jensen, M.C. and Meckling, W.H. (1976) 'Theory of the firm: Managerial behavior, agency costs and ownership structure', Journal of Financial Economics 3: 305-360.

Karpoff, J.M. and Lott Jr, J.R. (1993) 'The reputational penalty firms bear from committing criminal fraud', Journal of Law and Economics 36: 757-802.

La Porta, R., Lopez-de-Silanes, F., Shleifer, A. and Vishny, R. (2002) 'Investor protection and corporate valuation', Journal of Finance 57: 1147-1170.

Leuz, C., Nanda, D. and Wysocki, P.D. (2003) 'Earnings management and investor protection: An international comparison', Journal of Financial Economics 69: 505-527.

Mallin, C., Saadouni, B. and Bristol, R. (1995) 'The financial performance of ethical investment trust', Journal of Business Finance and Accounting 22: 483-496.

Margolis, J.D. and Walsh, J.P. (2001) People and profits? The search for a link between a company's social and financial performance, Mahwah, NJ: Lawrence Erlbaum Associates.

OECD (2003) 'Guidelines for Multinational Enterprises', fromwww.oecd.org/daf/investment/guidelines.

Orlitzky, M. and Benjamin, J.D. (2001) 'Corporate social performance and firm risk: A meta-analytic Review', Business \& Society 40: 369-396.

Orlitzky, M., Schmidt, F.L. and Rynes, S.L. (2003) 'Corporate social and financial performance: A metaanalysis', Business \& Society 24: 403-441.

Palmrose, Z. and Scholz, S. (2002) The circumstances and legal consequences of non-GAAP reporting: Evidence from restatements, Ontario: Contemporary Accounting Research conference.

Palmrose, Z., Richardson, V.J. and Scholz, S. (2001) Determinants of market reactions to restatement announcements, working paper, University of Southern California and University of Kansas.

Payne, L. (2003) Value shift: why companies must merge social and financial imperatives to achieve superior performance, New York: McGraw-Hill.

Reyes, M. and Grieb, T. (1998) 'The external performance of socially-responsible mutual funds', American Business Review 16: 1-7.

Romano, R. (2001) 'Less is more: Making shareholder activism a valuable mechanism of corporate governance', Yale Journal on Regulation 18: 174-232.

Shiller, R.J. (2003) The new financial order, Princeton: Princeton University Press.

Shleifer, A. and Vishny, R.W. (1997) 'A survey of corporate governance', Journal of Finance 52: 737-783.

Smith, M.P. (1996) 'Shareholder activism by institutional investors: Evidence from CalPERS', Journal of Finance 51: 227-252.

Williamson, O.E. (1985) The economic institutions of capitalism, New York: Free Press.

\section{About the Author}

Andrea Beltratti is professor of economics at the University of Bocconi, Italy. 